\title{
Education Quality Enhancement Through Open Education Adaptation
}

\author{
José Luis Martín Núñez \\ Instituto de Ciencias de la Educación \\ Universidad Politécnica de Madrid \\ Madrid, España \\ joseluis.martinn@upm.es

\section{Edmundo Tovar Caro} \\ Director OCW UPM \\ Facultad de Ingeniería Informática \\ Universidad Politécnica de Madrid \\ Madrid, España
}

\author{
Jesús Sánchez López \\ Escuela Técnica Superior de Ingeniería de Sistemas \\ Informáticos \\ Universidad Politécnica de Madrid \\ Madrid, España \\ Pilar Martínez García \\ Escuela Técnica Superior de Ingeniería de Sistemas \\ Informáticos \\ Universidad Politécnica de Madrid \\ Madrid, España
}

\begin{abstract}
Open Education is changing the educational paradigm. The consolidation of the OpenCourseWare initiative, supported by the top universities of the World, and the revolution generated in the recent years through the emergence of Massive Open Online Courses, present a new educational scenario for teachers, students and institutions. This new environment has furthered the use of e-learning, not only because of the benefits provided to students, such as flexibility of time and place, but also because anyone interested in training and learning, has access to a multitude of platforms with open resources and learning communities, not to mention the absence of admission processes or access requirements.
\end{abstract}

The majority of times, this kind of courses will be the first contact between universities and students, which is of high importance regarding the prestige of the institutions. The formation of thousands and even hundreds of thousands of people brings a challenge to teachers and their institutions, as they must be able to offer a course with very high quality to satisfy such a large number of students. For this reason, teachers need to develop new skills, such as managing multimedia elements or mass forums, to get an appropriate course to be published. As institutions are the final image and responsible for the courses, they must establish a process to monitor, facilitate and advise teachers to get an excellent final result.

This paper shows the adaptation process that a group of teachers have developed in order to publish a course in the OpenCourseWare platform of the Technical University of Madrid. In this case, these teachers and a group of experts from the institution worked as a team to enhance the course before publishing it. As a result, the satisfaction perceived by the students who used these new materials was increased, and the published course has received a large amount of visitors as an Open Educational Resource.

One of the strategic lines of the Open Education Office of the Technical University of Madrid is to promote the creation of Massive Open Online Courses from OpenCourseWare courses. This paper shows the benefits from this initiative. At this moment, the same group of teachers is developing the publication of this course as a Massive Open Online Course and many materials and multimedia resources need to be created. Besides, a new course design will be necessary to adapt the methodology to the massive conditions of the new model. To this point, teachers' opinions have been collected, and after the performance of this hard process, students' satisfaction and quality of the course will be measured to analyze the final results.

Keywords - Open Education; OpenCourseWare; Massive Open Online Courses; elearning quality

\section{INTRODUCTION}

Nowadays, online education has become one of the preferred methodologies among students and enterprises, due to the flexibility and work-life balance offered to students [1]. The advent of Open Education has contributed to elearning penetration. Not only students and teachers from universities and schools, but also anyone interested in training and learning has a multitude of platforms with open resources and learning communities available [2]. As happened with Open Source, Open Education has strengthened the confidence in the Online Educational Model [3].

In 2002, the Council on Educational Technology at the Massachusetts Institute of Technology (MIT) launched the MIT OpenCourseWare (OCW), created "to enhance the quality of MIT education through appropriate application of technology, to both on-campus life and learning and through distance learning" [4]. Since then, the OCW Consortium has grown explosively, and has become a place where top universities share their core academic courses using their materials (including syllabi, lecture, notes, assignments and examinations) [5]

The first program example of a full evaluation OCW was developed at MIT [6]. This model was adapted by many institutions and reissued several times [7][8][9], but these 
documents have marked the standards evolution of OCW and subsequent culture of evaluation and feedback of the OCW Consortium. In Spain most important universities have joined the Consortium, and specifically, Technical University of Madrid (UPM) has 153 public courses available in the OpenCourseWare project [10]

Moreover, the revolution of the Massive Open Online Courses (MOOC) is leading the way in Open Education. Projects like Edx or Coursera have experienced a higher growth than the Social Networks [11]. Teachers participating in these initiatives have to adapt to the new methodology, because they need to develop new skills to adapt their materials to the new model [12].

In this context, universities face the challenge of adapting to changing times. Open Educational Resources are an exponent of the emergence of new technologies and the expansion of the borders to share knowledge. This fact does not imply a weakening of the traditional roles, but an opportunity for quality Centers [13]. In this sense, according to A. Mulder, the current president of OCWC, the University continues to be the provider of educational content, although Internet has shared the information with many other institutions [14]. Moreover, we must not forget the importance of the official academic value of these new experiences, which tries to ensure the quality and educational worth of training through the Internet [15][16]. In fact, some authors [17] claim that the quality offered by MOOC is not obvious, and it is necessary to investigate the pedagogical quality of these systems [18].

At the Technical University of Madrid, the Office of Open Education is working to support the creation of MOOCs from the courses published at the OCW. The publishing process requires teachers and experts from the Office to review all materials and adapt them to the new methodology. This rigorous process ensures a higher quality course. Currently, Technical University of Madrid is working with MiriadaX, and there are 7 MOOCs avaliable in the complete catalog of the Website.

\section{WORK IN PROGRESS}

"Teleformación" is a course included in the offer of the Technical University of Madrid, which students can choose to complete their studies. Students can configure their academic profiles with these courses. Every year, this course is offered in the first six months of the academic course, and due to the general interest, all of the forty places offered are always filled.

Regarding the methodology of the course, it is structured in 10 modules, which are activated weekly. Each module activation enables materials to the students (pdf texts, PowerPoint presentations, additional documents...) and evaluations such as tests, short questions in forums, and teamwork projects.

Project-based learning is used along the entire course. Students make up project teams to create their own online course. This practice allows students to "learn by doing", as they develop a complete course with methodology, materials, and evaluation, followed by the configuration of these materials in a learning management system (Moodle 2.0). At the end of the course students are teachers, and in a role-play game, they evaluate the rest of the students in their courses and vice versa.

At the end of 2011, "Teleformación" teachers decided to participate in the OpenCourseWare project. Technical University of Madrid belongs to the OCW Consortium, and was the first Spanish university to join such an initiative. The UPM has an institutional policy of open access through which it promotes open access to knowledge. For this reason UPM has several open digital platforms with different objectives and characteristics, all complementary, not redundant, including its involvement in the OpenCourseWare (OCW) initiative. To participate in this initiative, it is necessary to make an application to the Open Education Office at the University. If the application is approved, the office assigns an expert who helps and advises teachers during the publishing process.

This publication process required teachers to review all materials carefully, and it was necessary to define a methodology of standardization. All teaching units should have a common structure and a similar appearance. The process was performed with the following considerations:

- Designing a teaching guide that includes objectives, program, general course information, assessment, and all aspects of teaching methodology.

- Adaptation of the information and materials to an audience that may be unfamiliar with the environment, context, and other resources available in the traditional class.

- Dividing the entire course, forming teaching units with a similar weekly structure. Defining a template to be used in all documents, getting materials with a similar appearance easily recognized by students, trying to be homogeneous, with intuitive access similar to other OCW.

- Incorporating accurate metadata into the OCW Consortium, in order to facilitate search functions, cataloging and OCW site access from any location. This will be very important to present the subject and get many visitors.

- Completing materials, and especially the more complex issues, with some external references with which students can broaden their knowledge.

- Studying and evaluating the resolution of potential intellectual property issues. Teachers must ensure that material posted on the OCW site is original or they have sharing permission, either directly by ownership or through the license that supports them to be reused without infringing "copyrights".

- Developing an evaluation associated with each learning unit, which allows a progressive learning, interrelating concepts for reaching a final exercise integrator.

- Reviewing the accessibility criteria for all materials to ensure access to anyone interested.

According to the point of view of teachers who participated in the process, this work was not very difficult, but very 
laborious. It took about four months, because they had to review all materials in detail, improving their quality before being published on the OCW platform. They are currently conducting a study to evaluate the perceived quality of new students who are using these materials.

In late 2012 the subject was published in the OCW space of the Technical University of Madrid. This website currently provides access to 153 full courses, classified by knowledge area. Some of the subjects, as in the case of "Producción Avicola" ("Poultry Production") have more than two hundreds thousands of hits on their materials since its publication in Septembre 2008 [10].

Shortly afterwards, in December 2012, the project MiriadaX started to develop the first MOOCs. Particularly, one of the strategic lines of the Open Education Office of the Technical University of Madrid is to promote the creation of Massive Open Online Courses from OpenCourseWare courses. For this reason, UPM encouraged teachers to participate in this project, and especially teachers who had participated in the OCW project. In this case, teachers should elaborate a course to be opened and followed massively. At that time, "Teleformación" teachers decided to start an educational innovation project to publish this subject in MOOC format.

Currently, teachers are working on redesigning the course, because the material is very elaborated but mainly based on texts and presentations, and the MOOC format requires many video presentations. In this case it is necessary to train teachers to handle video tools, so they will be able to create videos that students can view and understand the materials without much more support. The teachers are performing these changes with the following considerations:

- Dividing the learning units into small illustrative videos, reducing the more theoretical parts linking to OCW materials, and expanding practices that require greater precision. For example, explaining the use of specific software or making an installation.

- Creating an attractive program to keep students interested progressively, increasing complexity and avoiding potential dropouts.

- Simplifying the evaluation, resulting in two types of evaluating elements. On the one hand, exercise tests to evaluate after each video lesson, and on the other hand, p2p exercises performing a task and assessing other peers.

- Engaging students, by developing dynamic exercises that encourage communication between them, so they can share experiences, documents, achievements, upgrades, etc.

- Revising course planning and providing more flexibility. Developing a communication plan to accompany the students encouraging them along the course with reminder messages.

- Designing a system of data collection, such as student surveys, analysis of discussion forums and other procedures that allow teachers to diagnose the stage of completion of the course, in case it is necessary to make any kind of decision to redirect the progress of the course.

- Keeping the "Learning by doing" philosophy, offering graduates a complete online teaching experience, and the possibility to work with other people with the same motivations and interests.

The MOOC will be sent to the MiriadaX platform. This project is growing rapidly: in its first year exceeded two hundred fifty thousand registered in the 59 courses of 28 universities from 6 different countries. Teachers are already registered in the platform and are being formed on how to manage a course. This Website offers a MOOC called "Cómo crear un MOOC en MiriadaX" "How to create a MOOC in MiriadaX"), in which it is explained how to create materials, activities, forums, questionnaires, surveys, etc. and a best practices guide is provided.

\section{PRELIMINARY RESUlts}

The "Teleformación" course quality has improved considerably since its publication in Open Education process. The documentation review process has been very intense, but it became homogeneous and with very complete documents fully aligned with a Learning Guide. Up to this moment, according to the OCW website of the Technical University of Madrid, "Teleformación" has received a total of 829 visits, more than one visit per day. Hits are distributed as shown in figure 1 . We can see a greater number of hits in 2012 than in 2013. This may be due to the difference in number of students enrolled in the "Teleformación" course, as students in this course use OCW materials as educational resources. During the 2012/13 course there were 33 students, decreasing to 15 students in the 2013/14 course.

It is expected that these numbers grow considerably after the subject is published in MOOC format. The following figure shows the visits to the "Teleformación" course available on OCW-UPM platform since its publication [19].

La asignatura: Teleformación ha recibido: 829 visitas entre las fechas:

01-01-2012 y el o8-04-2014

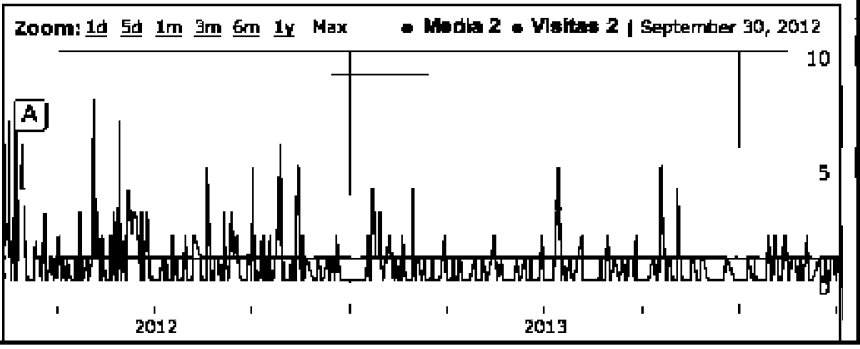

Fig. 1. "Teleformación” Access (OCW Platform UPM)

In this case, for the MOOC publication, teachers are preparing new materials and content reviews. They are updating and simplifying its structure. It is essential to take into consideration the massive format and the human limitations to solve questions. Because of this, it is important to offer many documents and references to facilitate self-study. Thereby, doubts and questions will be reduced. 
The course is imparted once a year and at the end, a quality survey is sent to students. One of the questions included in the questionnaire seeks to measure the quality perceived by the students regarding documentation. In the last three years the same survey has been made to students in different classes. The total number of students is 86 , from which 45 samples were collected.

We can see a clear trend in the improvement of the assessments made by the students. We are currently conducting a more rigorous study to determine the significance of the observed results. The following table shows the results, with the average value in Likert scale (1-5) and its variance.

\begin{tabular}{|c|c|c|c|}
\multicolumn{1}{|c|}{ TABLE I. } & $\begin{array}{c}\text { SURVEY RESULTS “TELEFORMACIÓN": QUALITY } \\
\text { DOCUMENTATION }\end{array}$ \\
\hline & \multicolumn{4}{|c|}{ Quality of documentation } \\
\hline Academic Year & $\mathbf{2 0 1 1 / 2 0 1 2}$ & $\mathbf{2 0 1 2 / 2 0 1 3}$ & $\mathbf{2 0 1 3 / 2 0 1 4}$ \\
\hline Mean (SD) & $4,13(0,83)$ & $4,3(0,77)$ & $4,5(0,57)$ \\
\hline
\end{tabular}

Last but not least, teachers have improved their teaching skills in this process. They have learned innovative systems and new methodologies. And after mastering the management of these tools they will develop complete multimedia materials of higher quality. These materials will be included in the creation of the MOOC, but also in the traditional course and an improvement is expected in the multimedia quality perceived by the students.

\section{CONCLUSION}

Despite being an investigation under completion, there are many success indicators. Currently, surveys are being developed, as well as other methods to collect data and contrast these results. Meanwhile, the teachers conclude that they have noticed a remarkable improvement in the quality of the course after these different initiatives. Not only the quality of the materials and resources has improved, but also internal processes, teacher communication, and strategic alignment to achieve the objectives with the completion of the course.

\section{ACKNOWLEDGMENT}

This research is partially funded by the Educational Innovation Group of the Technical University of Madrid "Gestytec".
Zhang Dongsong, J. Leon Zhao, Lina Zhou and Jay F. Nunamaker Jr. 2004. "Can e-learning replace classroom learning?." Communications of the ACM. Vol. 47 (5), pp. 75-79.

Brown John Seely and Richard P. Adler. 2008. "Open education, the long tail, and learning 2.0." Educause review. Vol. 43 (1), pp. 16-20.

Baldi Stefan, Hauke Heier and Anett Mehler-Bicher. 2003. "Open courseware and open source software." Communications of the ACM. Vol. 46 (9), pp. 105-107.

Abelson, Hal. 2008. "The creation of opencourseware at MIT." Journal of Science Education and Technology. Vol. 17 (2), pp. 164-174.

Carson, Steve. 2009. "The unwalled garden: Growth of the opencourseware consortium, 2001-2008." Open Learning. Vol.24 (1), pp. 23-29.

Carson, Stephen E. 2004. MIT OpenCourseWare program evaluation findings report. Cambridge, MA.

OpenCourseWare, MIT. 2005. Program Evaluation Findings Summary. Massachusetts Institute of Technology OpenCourseWare, Massachusetts.

OpenCourseWare, MIT. 2009. Program Evaluation Findings Summary. Massachusetts Institute of Technology OpenCourseWare, Massachusetts.

OpenCourseWare, MIT. 2011. Program Evaluation Findings Summary. Massachusetts Institute of Technology OpenCourseWare, Massachusetts.

"Technical University of Madrid OpenCourseWare homepage". Technical University of Madrid (UPM), http://ocw.upm.es. Accessed: 8 April 2014.

Pappano, Laura. 2012. "The year of the MOOC." The New York Times. Vol.2 (12).

Kellogg, Sarah. 2013. "Online learning: How to make a MOOC." Nature. Vol. 499 (7458), pp. 369-371.

Tovar, Edmundo. 2013. "Aplicación de tecnologías web emergentes para el estudio del impacto de repositorios OpenCourse Ware españoles y latinoamericanos en la Educación Superior". http://ocw.upm.es/informefinal-ocw. Accessed: 8 April 2014.

Mulder, Anka. 2011. "Open Educational Resources and the Role of the University." Educause Review. Vol .46 (5), pp 8-9.

Aguaded, José Ignacio. 2013. "La revolución MOOCs, ¿una nueva educación desde el paradigma tecnológico?". Comunicar, Vol. 41, pp. 78.

Guàrdia, Lourdes, Marcelo Maina and Albert Sangrà. 2013. "MOOC Design Principles. A Pedagogical Approach from the Learner's Perspective". eLearning Papers. Vol. 33.

Martín, Oscar, Francisco González and María de los Ángeles García. (2013). Propuesta de evaluación de la calidad de los MOOC a partir de la Guía Afortic. Campus Virtuales, Vol. 2 (1), pp. 124-132.

Roig Vila, Rosa Isabel, Santiago Mengual Andrés and Cristobal Suárez Guerrero. (2014). Evaluación de la calidad pedagógica de los MOOC. Revista de curriculum y formación del profesorado. Vol. 18 (1).

"Teleformación course OpenCourseWare". Technical University of Madrid (UPM). $\quad \underline{\text { http://ocw.upm.es/lenguajes-y-sistemas- }}$ informaticos/teleformacion Accessed: 8 April 2014. 